\title{
G $\beta 5$ Is Required for Normal Light Responses and Morphology of Retinal ON-Bipolar Cells
}

\author{
Anjali Rao, ${ }^{1}$ Rebecca Dallman, ${ }^{1}$ Scott Henderson, ${ }^{2}$ and Ching-Kang Chen ${ }^{1}$ \\ ${ }^{1}$ Departments of Biochemistry and Molecular Biology and ${ }^{2}$ Anatomy and Neurobiology, Virginia Commonwealth University, Richmond, Virginia 23298
}

$\mathrm{G} \beta 5$ exists as two splice variants, $\mathrm{G} \beta 5$-S and G $\beta 5$-L, which interact with and stabilize the R7 members of the regulators of G-protein signaling (RGSs): RGS6, RGS7, RGS9, and RGS11. Although the role of G $\beta 5$-L and RGS9-1 is established in photoreceptors, the physiological functions of G $\beta 5$-S and other R7 RGS proteins remain unclear. We found that the electroretinogram of G $\beta 5^{-1-}$ mice lacks the b-wave component and that G $\beta 5$-S and RGS11 colocalize with Go $\alpha$ at the tips of the ON-bipolar cell dendrites. Unexpectedly, we found a significant reduction in the number of synaptic triads in the outer plexiform layer $(\mathrm{OPL})$ of the $\mathrm{G} \beta 5^{-1-}$ mice, which is evident at postnatal day 14. Transgenic expression of G $\beta 5$-L in rods failed to rescue the b-wave or the OPL defects. These results indicate that G $\beta 5-S$ is indispensable for OPL integrity and normal light responses of the retina.

Key words: bipolar cells; RGS; retina; G $\beta 5$; morphology; ERG

\section{Introduction}

G $\beta 5$ is the fifth member of the heterotrimeric G-protein $\beta$-subunit family (Watson et al., 1994). It exists as two alternatively spliced forms: the photoreceptor-specific long form (G $\beta 5-L)$ and the broadly expressed short form (G $\beta 5-S)$, which lacks the first exon (Watson et al., 1996). Unlike the other four conventional G-protein $\beta$-subunits, G $\beta 5$ interacts with the GGL (G-protein- $\gamma$-like) domain found in the R7 members of the regulators of G-protein signaling (RGSs) (Snow et al., 1998). This interaction confers mutual stability to $G \beta 5$ and its partners (Witherow et al., 2000). In retinas of the $\mathrm{G} \beta 5^{-1-}$ mice, the levels of RGS6, 7, and 11 are downregulated below detection, whereas RGS9-1 falls to $\sim 3 \%$ of the control level (Chen et al., 2003). In the $\mathrm{RGS}^{-1-}$ mice, $\mathrm{G} \beta 5$-L is undetectable, whereas $\mathrm{G} \beta 5$-S level remains normal (Chen et al., 2000). Recordings from rods of $\mathrm{GBS}^{-1-}$ (Krispel et al., 2003), RGS9 ${ }^{-1-}$ (Chen et al., 2000), and

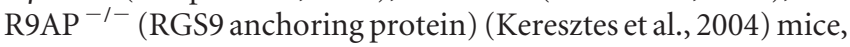
which displayed similar and prolonged recovery of rod photoresponses, have established the role of G $\beta 5$-L/RGS9-1/R9AP as the GTPase accelerating protein complex (GAP) for transducin $\alpha$-subunit (Gt $\alpha$ ). The GAP activity resides in the RGS domain of RGS9-1, whereas G $\beta 5$-L and R9AP confer intracellular stability, membrane affinity, and outer segment targeting modality to the complex (Chen et al., 2003; Martemyanov et al., 2003; Keresztes et al., 2004). Because G $\beta 5$-L expression is restricted to the pho-

Received Jan. 31, 2007; revised Nov. 15, 2007; accepted Nov. 15, 2007.

This work was supported by National Institutes of Health (NIH) Grant EY013811 (C.K.C.). Transmission electron microscopy was performed at the Department of Neurobiology and Anatomy Microscopy Facility, supported in part by funding from NIH-National Institute of Neurological Disorders and Stroke Grant 5P30NS047463. Confocal microscopy was performed at the Massey Cancer Center, supported in part by NIH Grant 1P30CA16059. We thank Judy Williamson for assistance with electron microscopy and Lawrence Lanberg for ultramicrotomy.

Correspondence should be addressed to Dr. Ching-Kang Jason Chen, Department of Biochemistry and Molecular Biology, Box 980614, Virginia Commonwealth University, 1101 E. Marshall Street, Room 2-032b, Richmond, VA 23298. E-mail:cjchen@vcu.edu.

DOI:10.1523/JNEUROSCI.4934-07.2007

Copyright $\odot 2007$ Society for Neuroscience $\quad$ 0270-6474/07/2714199-06\$15.00/0 toreceptors, we have further characterized the $\mathrm{G} \beta 5^{-1-}$ animals to study the physiological function of G $\beta 5$-S and other R7 RGS proteins. Here we report that the scotopic and photopic electroretinogram (ERG) b-waves are absent in the $\mathrm{G} \beta 5^{-1-}$ mice. In addition, we show that G $\beta 5-S$ along with RGS11 is expressed at the tips of the ON-bipolar cell dendrites, where ERG b-wave originates. Unexpectedly, we also found that the synapses between photoreceptors and bipolar cells develop abnormally in the absence of $\mathrm{G} \beta 5$. These data indicate a hitherto unknown role of $\mathrm{G} \beta 5-\mathrm{S}$ in synaptic formation at the retinal outer plexiform layer (OPL) and suggest a role of G $\beta 5$-S/RGS7 and/or G $\beta 5$-S/RGS11 in normal bipolar cell light responses.

\section{Materials and Methods}

Animals. The $\mathrm{G} \beta 5^{-1-}$ mice are maintained in a mixed background of C57BL/6 and 129SvEv. The TG $\beta 5 \mathrm{~L}$ transgenic line was generated by injecting the embryos of C57BL/6 and SJL parents with a DNA construct (see Fig. $1 B$ ) containing a C-terminal FLAG-tagged G $\beta 5$-L cDNA placed downstream of a $4 \mathrm{~kb}$ rhodopsin promoter and upstream of a mouse protamine polyadenylation signal. Founders were identified by the presence of a 550 bp PCR product using the following primers: RH1.1: $5^{\prime}$ TCA GTG CCT GGA GTT GCG CT and G $\beta 5-510 \mathrm{R}: 5^{\prime}$-CTT ATT ATC CAG ACC ACC AC. The TG $\beta 5 \mathrm{~L}^{-1-}$ mice were generated by breeding the TG $\beta 5 \mathrm{~L}$ mice with the $\mathrm{G} \beta 5^{-1-}$ mice and maintained in a mixed background of C57BL/6, 129SvEv, and SJL. The $r d 1$ allele at the Pde6b locus intrinsic to the SJL background was identified by PCR (Pittler and Baehr, 1991) and eliminated. Littermate heterozygotes or age-matched C57BL/6 mice were used as controls. All studied were performed in accordance with the rules and regulations of the National Institutes of Health guidelines for research animals and approved by the institutional animal care and use committee at the Virginia Commonwealth University.

Immunohistochemistry. The mice were killed by $\mathrm{CO}_{2}$ inhalation followed by cervical dislocation. Eyeballs were enucleated immediately after the mice were killed and immersion fixed in $4 \%$ paraformaldehyde in PBS for 30 min and cryoprotected overnight in 30\% sucrose in PBS at $4^{\circ} \mathrm{C}$. They were embedded in TBS (Richard Allan Scientific, Kalamazoo, 
Table 1. Sources and dilution of primary antibodies used in immunocytochemistry

\begin{tabular}{llc}
\hline Antibody & Source & Dilution \\
\hline G $\beta 5$ (CT215) & Watson et al. (1994) & $1: 500$ \\
RGS7 (2923AP) & Chen et al. (2003) & $1: 100$ \\
RGS11 ( $\alpha$ S-11) & Chen et al. (2003) & $1: 100$ \\
RGS6 & Imgenex (San Diego, CA) & $1: 100$ \\
Go $\alpha$ & Millipore (Billerica, MA) & $1: 100$ \\
mGluR6 & Neuromics (Northfield, MN) & $1: 100$ \\
PKC $\alpha$ & Sigma & $1: 100$ \\
FLAG & Sigma & $1: 100$ \\
\hline
\end{tabular}

$\mathrm{MI})$, and $12 \mu \mathrm{m}$ cryosections were prepared and stored at $-80^{\circ} \mathrm{C}$. When staining, sections were thawed, washed, and blocked with $10 \%$ goat or donkey serum with $0.3 \%$ Triton X-100 in PBS for $1 \mathrm{~h}$, followed by overnight incubation at room temperature with appropriate dilutions of primary antibodies (Table 1). Dye-conjugated secondary antibodies were used at 1:100 and incubated for $1 \mathrm{~h}$ at room temperature. For reliable detection of G $\beta 5$, RGS7, and RGS11, tyramide signal amplification kit (Invitrogen, Carlsbad, CA) was used by following the manufacturer's instructions. After incubation with secondary antibodies, sections were washed three times with PBS for 10 min each and sealed in Vectashield (Vector Laboratories, Burlingame, CA), and the fluorescent images were captured using a Zeiss (Thornwood, NY) LSM 510 Meta confocal microscope. For analyses of dendritic morphology of rod bipolar cells in the OPL (see Fig. 2G,H), $z$-stacks spanning a total of $7 \mu \mathrm{m}$ were taken and rotated on the $x$ - or $y$-axis to correct for cutting-angle artifacts. OPL images shown were taken at the superior meridian of retinal sections containing the optic nerve head (ONH).

Transmission electron microscopy. The enucleated eyeballs were immersion fixed overnight with $2 \%$ paraformaldehyde/ $2 \%$ glutaraldehyde in $0.1 \mathrm{~m}$ phosphate buffer, $\mathrm{pH} 7.4$, at room temperature and processed as described previously ( $\mathrm{Li}$ et al., 2005). Ultrathin sections $(100 \mathrm{~nm})$ were prepared using a Sorvall MT-6000 ultramicrotome. Sections were stained with uranyl acetate and lead citrate and imaged using a Joel JEM-1230 transmission electron microscope. For quantification of OPL synaptic triads and ribbons in Figure $3 C-F$, three sets of age-matched control, $\mathrm{G} \beta 5^{-1-}$, or TG $\beta 5 \mathrm{~L}^{-1-}$ animals were used per indicated postnatal age. For rod spherules, 20 random and nonoverlapped $38 \times 38 \mu \mathrm{m}$ transmission electron microscopy (TEM) images between the meridian and the $\mathrm{ONH}$ were analyzed per mouse eye. For cone pedicles, triads and ribbons were counted from 20 to 30 cone pedicles per mouse eye. All images were obtained with retinal sections containing the ONH. The difference in each measurement between the genotypes was examined by one-way ANOVA with $p$ values $<0.01$ considered significant.

Electroretinography. Mice were dark adapted for 16-24 h and anesthetized using ketamine/xylazine (150 and $10 \mathrm{mg} / \mathrm{kg}$, i.p.). The eyes were dilated with $1 \%$ atropine sulfate (Falcon Laboratories, Forth Worth, TX). ERG recordings were performed using the UTAS E-3000 system (LKC Technologies, Gaithersburg, MD) under scotopic and photopic $\left(30 \mathrm{~cd} / \mathrm{m}^{2}\right)$ conditions as previously described (Li et al., 2005), except that responses from both eyes were recorded simultaneously but analyzed individually. Typically the difference in the A-wave amplitudes between the two eyes of the same animal was $<10 \%$. Three to 15 responses were collected and averaged for each stimulus intensity. The

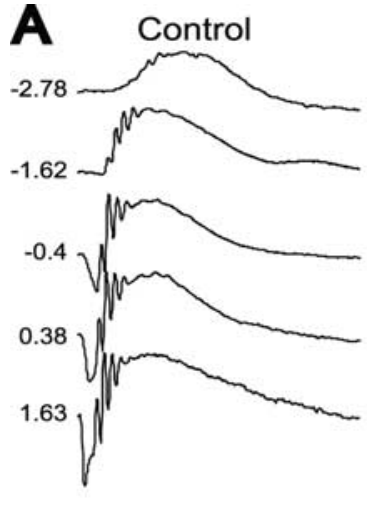

E

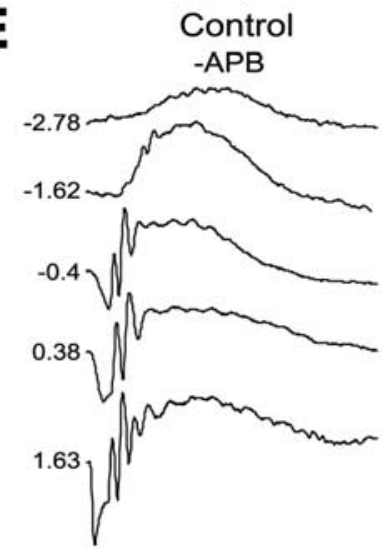

G $\beta 5$ - / -
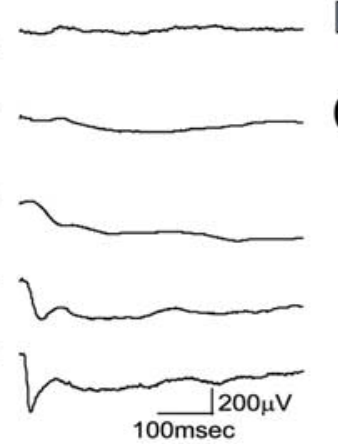

C

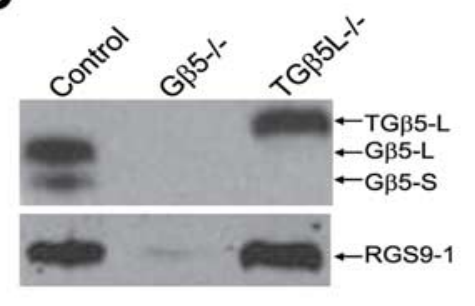

\section{Control} + APB
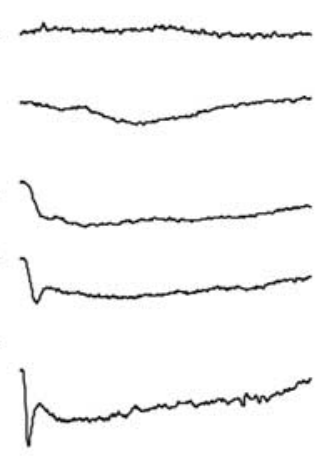

TG $\beta 5$ L-/-APB

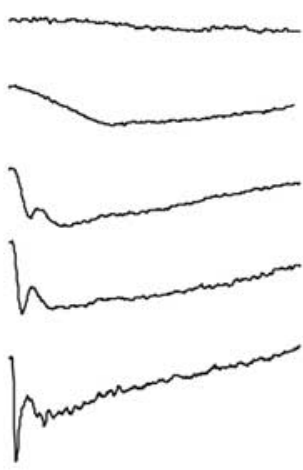

D

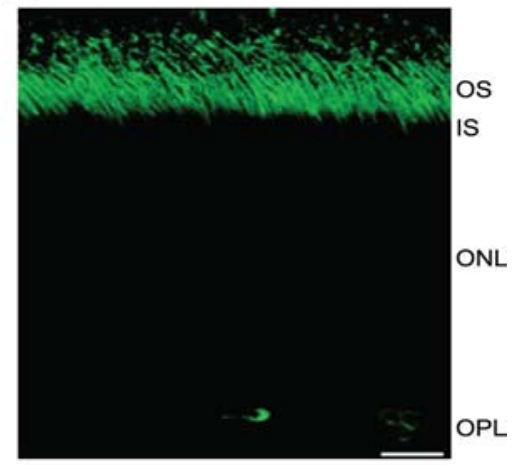

TG $\beta 5$ L-/+ APB

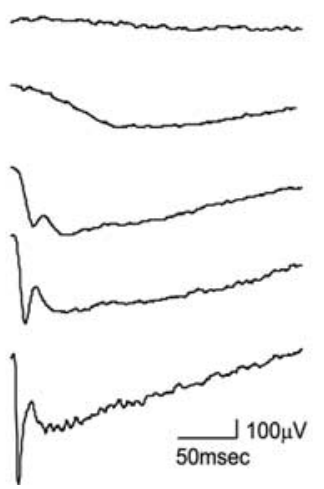

Figure 1. The postphotoreceptoral electroretinographic no-b-wave phenotype of the $\mathrm{G} \beta 5^{-/-}$mice. $A$, Representative scotopic ERG responses of dark-adapted adult control (left) and $\mathrm{G} \beta 5^{-1-}$ mice (right) to a series of white flashes with indicated intensities in $\log \mathrm{cd} \mathrm{s} / \mathrm{m}^{2}$. B, DNA construct used for the generation of TG $\beta 5 \mathrm{~L}$ transgenic mice. C, Western blots showing $\mathrm{G} \beta 5$ and RGS9-1 levels in $10 \mu \mathrm{g}$ extracts of control, $\mathrm{G} \beta 5^{-1-}$, and TG $\beta 5 \mathrm{~L}^{-1-}$ mouse retinas. D, Image of a TG $\beta 5 \mathrm{~L}^{-1-}$ retinal section probed with a Flag antibody showing outer segment localization of the transgenic product. OS, Outer segment; IS, inner segment. Scale bar, $10 \mu \mathrm{m}$. $E$, Representative scotopic ERG responses of dark-adapted control (left) and TG $\beta 5 \mathrm{~L}^{-1-}$ mice (right), treated or untreated with APB. 
interstimulus interval ranges from 5 to $120 \mathrm{~s}$ for control and TG $\beta 5 \mathrm{~L}^{-1-}$ animals. For $\mathrm{G} \beta 5^{-1-}$ mice, it ranges from 30 to $>600 \mathrm{~s}$ to ensure full photoreceptor recovery. For intravitreal delivery, $2 \mu \mathrm{l}$ of $11 \mathrm{~mm}$ L-2-amino-4-phosphonobutyric acid (APB) (Sigma, St. Louis, MO) dissolved in PBS was injected into the right eye under anesthesia in the dark using pulled-glass pipettes and a pneumatic Picopump. The final APB concentration was estimated to be $2.2 \mathrm{~mm}$ assuming an eyeball volume of $10 \mu \mathrm{l}$. The left eye was subsequently injected with PBS and served as control. Animals were allowed to recover from eye injections for $40 \mathrm{~min}$ in darkness before ERG recordings ensued.

\section{Results \\ $\mathrm{G} \beta 5^{-/-}$and TG $\beta 5 \mathrm{~L}^{-1-}$ mice lack \\ ERG b-waves}

The scotopic ERG responses of darkadapted $\mathrm{G} \beta 5^{-/-}$mice exhibited waveforms distinctive to those of the controls, indicating the absence of the b-wave component (Fig. 1A). Photopic ERG, isolated by $0.01 \mathrm{~Hz}$ of flickering $80 \mathrm{~cd} \mathrm{~s} / \mathrm{m}^{2}$ flashes, also revealed the absence of a b-wave (data not shown). ERG b-wave originates from the ON-bipolar cells (Stockton and Slaughter, 1989) and may be affected by postsynaptic or presynaptic defects at the OPL (Masu et al., 1995; Mansergh et al., 2005). G $\beta 5^{-1-}$ mice have delayed phototransduction recovery because of the absence of the transducin GAP complex in photoreceptors. This defect is not expected to cause the no-b-wave phenotype because ERG b-wave is present in the RGS9 ${ }^{-/-}$mice, which have a phototransduction recovery defect similar to that of $\mathrm{G} \beta 5^{-/-}$mice (Lyubarsky et al., 2001). To further confirm this, we created a transgenic mouse line, TG $\beta 5 \mathrm{~L}^{-1-}$, in which a FLAG-tagged $\mathrm{G} \beta 5-\mathrm{L}$ is expressed in rods of the $\mathrm{G} \beta 5^{-1-}$ mice. The tagged $\mathrm{G} \beta 5$-L restores the level of RGS9-1 (Fig. 1C) and is found in the outer segments (Fig. 1D). The dominant recovery time constants $\left(\tau_{\mathrm{D}}\right)$ for control and $\mathrm{G} \beta 5^{-1-}$ rods were previously determined by suction recordings to be 260 and $2700 \mathrm{~ms}$, respectively (Krispel et al., 2003). Using double flash ERG recordings, we found comparable $\tau_{\mathrm{D}}$ for the TG $\beta 5 \mathrm{~L}^{-1-}(235 \pm 8 \mathrm{~ms}, n=15)$ and the control animals (189 \pm $12 \mathrm{~ms}, n=17)$. Despite the rescue of the rod recovery defect, the scotopic ERG responses of the TG $\beta 5 \mathrm{~L}^{-/-}$mice revealed a phenotype similar to that of the $\mathrm{G} \beta 5^{-1-}$ mice (Fig. $1 E$ ). The origin of the no-b-wave phenotype of the $\mathrm{G} \beta 5^{-/-}$mice is thus determined to be postphotoreceptoral.

To examine whether the b-wave is completely or partially lost in the TG $\beta 5 \mathrm{~L}^{-1-}$ mice, we compared the ERG responses with and without the treatment of APB, an agonist of the group III metabotropic glutamate receptors (Slaughter and Miller, 1981). As shown in Figure $1 E$, in control animals APB changes the retinal light responses by eliminating the ERG b-wave of the treated eyes but not in the untreated ones. Similar treatments to the TG $\beta 5 \mathrm{~L}^{-1-}$ animals cause minimal changes to ERG waveforms (Fig. $1 E$ ), suggesting that ERG b-wave is completely lost when $\mathrm{G} \beta 5-\mathrm{S}$ is absent. There is a small positive component immediately following the a-wave in the TG $\beta 5 \mathrm{~L}^{-1-}$ ERG responses under higher stimulus intensities. This upward potential is also
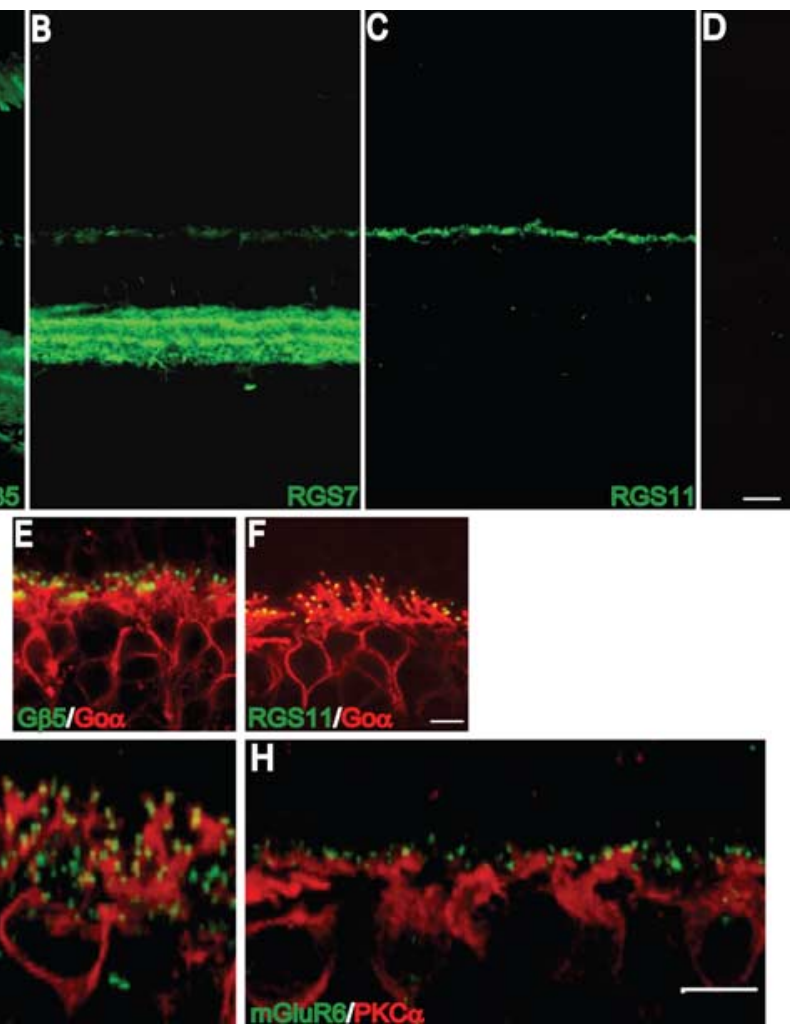

H

Figure 2. Localization of $\mathrm{G} \beta 5, \mathrm{RGS7}$, and $\mathrm{RGS} 11$ in the retina and abnormal $0 \mathrm{~N}$-bipolar cell morphology of the $\mathrm{G} \beta 5^{-1-}$ mice control retinas. Scale bar, $5 \mu \mathrm{m} . \boldsymbol{G}, \boldsymbol{H}$, Retinal sections from age-matched adult control $(\boldsymbol{G})$ and $\mathrm{G} \beta 5^{-1-}$ animals $(\boldsymbol{H})$ colabeled

present in APB treated control animals and may reflect the activity of hyperpolarization-activated and cyclic nucleotide gated channels present in the inner segments of the photoreceptors (Fain et al., 1978).

\section{$\mathrm{G} \beta 5^{-/-}$mice display abnormal rod bipolar cell morphology}

The downregulation of the R7 RGS proteins in $\mathrm{G} \beta 5^{-/-}$mouse retinas facilitates the examination of their expression by immunocytochemistry (Fig. 2). We found that G $\beta 5$, RGS7, and RGS11 are localized to the OPL and that the inner plexiform layer contains G $\beta 5$ and RGS7. Additionally, we discovered that G $\beta 5$ and RGS11 colocalize with Go $\alpha$ at the dendritic tips of the ONbipolar cells (Fig. 2E,F). Attempts to localize RGS6 were hampered by the lack of good antibodies for murine RGS6. However, we found a commercial antibody (Table 1) that stained the cholinergic synaptic terminals of the control and not the $\mathrm{G} \beta 5^{-/-}$ animals (data not shown). Because the no-b-wave ERG phenotype of the $\mathrm{G} \beta 5^{-1-}$ mice originates from postphotoreceptoral loss of G $\beta 5$-S, we further investigated the morphology of the rod bipolar cells marked by PKC $\alpha$ and mGluR6. As shown in Figure $2 G$, OPL of the control mice showed elaborate dendritic branching of rod bipolar cells capped with mGluR6. In contrast, the OPL of the $\mathrm{G} \beta 5^{-/-}$mice appears disorganized with shorter dendrites (Fig. $2 H$ ), suggesting gross morphological abnormalities. This finding is in contrast to the normal OPL morphology reported for three other mouse lines with known postphotoreceptoral origin of similar no-b-wave phenotype, namely mGluR6 ${ }^{-1-}$ (Tagawa et al., 1999), Go $\alpha^{-/-}$(Dhingra et al., 2000), and nob (Ball et al., 2003). 
A
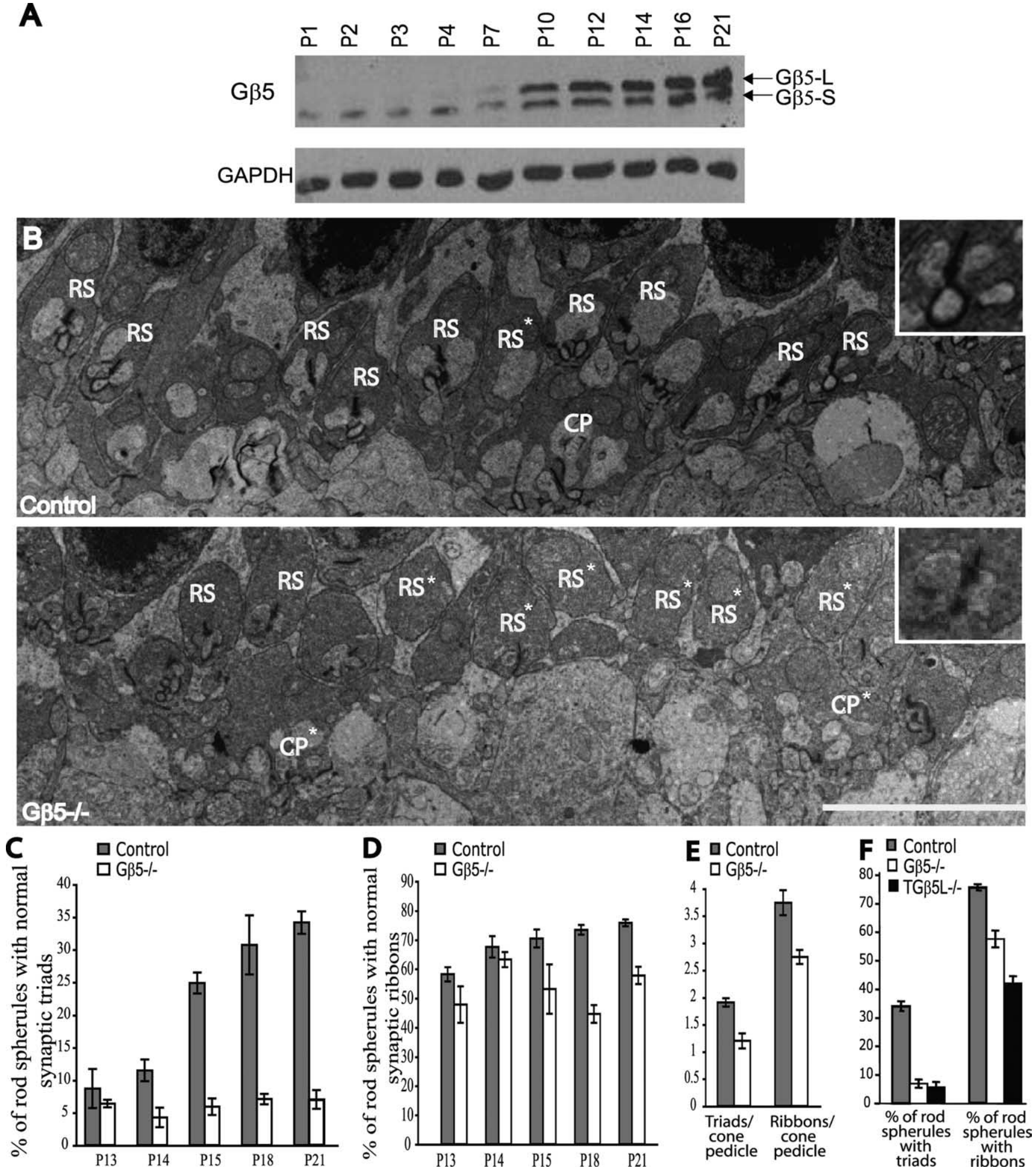

Figure 3. Abnormal OPL ultrastructure of the $\mathrm{G} \beta 5^{-/-}$mice. $A$, Western blot analyses of $10 \mu \mathrm{g}$ retinal extracts of control mice at indicated postnatal ages showing relative levels of $\mathrm{G} \beta 5$-S and $\mathrm{G} \beta 5$-L in reference to glyceraldehyde-3-phosphate dehydrogenase (GAPDH) level. B, TEM images of the OPL of the control (top) and G $\beta 5^{-1-}$ (bottom) mice. Scale bar, $5 \mu \mathrm{m}$. RS, Rod spherule; CP, cone pedicle. Asterisk denotes abnormal structures found in the $G \beta 5^{-1-}$ retina. Representative OPL synapses are shown in insets. $\boldsymbol{C}, \boldsymbol{D}$, The averaged percentage of rod spherules with normal synaptic triads $(\boldsymbol{C})$ and ribbons $(\boldsymbol{D})$ at indicated postnatal days. Error bars are SEM $(n=3) . \boldsymbol{E}$, The averaged number of synaptic triads and ribbons found per cone pedicle per section in adult control and $\mathrm{G} \beta 5^{-1-}$ mice, $n=3 . \boldsymbol{F}$, The averaged percentage of rod spherules with triads and ribbons in adult $\mathrm{TG} \beta 5 \mathrm{~L}^{-/-}$mice compared with age-matched $\mathrm{G} \beta 5^{-/-}$and control animals, $n=3$.

Rod synaptic triads in the OPL of the $\mathrm{G} \beta 5^{-/-}$mice fail to develop properly

The morphological defects at the OPL of the $\mathrm{G} \beta 5^{-/-}$mice could result from maintenance failure, developmental defect, or both.
We found that G $\beta 5-S$ is detectable in retinal extracts as early as postnatal day 1 (P1), with a sharp increase from P7 to P10 and plateaus to the adult level at P21 (Fig. 3A). The expression profile of $\mathrm{G} \beta 5-\mathrm{S}$ is consistent with the notion that it plays a role in retinal 
development. In addition, we found that the typical three to four tiers of rod synaptic triads of normal OPL at P21 are reduced to one or two in aged-matched $\mathrm{G} \beta 5^{-/-}$mice (Fig. $3 B$, top vs bottom). The rod synaptic triads of the control animals typically possess three postsynaptic elements consisting of two lateral dendrites of the horizontal cells and a central one/two ON-bipolar cell dendrites and a presynaptic ribbon (Kolb, 1977). In contrast, most of the rod spherules in the $G \beta 5^{-1-}$ mice lack the central bipolar cell dendritic element (Fig. $3 B$, bottom). By analysis of $\mathrm{OPL}$ in the wild-type and $\mathrm{G} \beta 5^{-1-}$ mice, we found that the number of rod spherules between the two genotypes are similar $(12 \pm$ 0.38 and $12 \pm 0.34$ for WT and $\mathrm{G} \beta 5^{-/-}$mice, respectively, over a $38 \times 38 \mu \mathrm{m}$ OPL area), but the percentage of rod termini with normal synaptic triads in P21 G $\beta 5^{-1-}$ mice are reduced approximately fivefold compared with those of age-matched control animals (Fig. $3 C$ ). The percentage of control rod termini with triads increased steadily from $8.6 \pm 2.9 \%$ at $\mathrm{P} 13$ to $34.1 \pm 1.6 \%$ at $\mathrm{P} 21$. However, regardless of the age of the $\mathrm{G} \beta 5^{-/-}$animals, the numbers were consistently below the level of the P13 control animals. A small but statistically significant reduction in the percentage of rod termini with ribbons beyond P15 was noted in G $\beta 5^{-1-}$ and TG $\beta 5 \mathrm{~L}^{-1-}$ mice (Fig. $3 D, F$ ). Furthermore, we found $\sim 2 \pm 0.08$ and $1 \pm 0.14$ synaptic triads per cone pedicle for wild-type and $\mathrm{G} \beta 5^{-1-}$ mice, respectively (Fig. $\left.3 E\right)(p=0.0009)$. The numbers of ribbons per cone pedicle for wild-type and $\mathrm{G} \beta 5^{-1-}$ mice were $4 \pm 0.23$ and $3 \pm 0.13$, respectively $(p=0.0004)$. These data indicate that synaptic connection between bipolar cells and photoreceptors are abnormal in the $\mathrm{G} \beta 5^{-/-}$animals. Transgenic expression of a tagged G $\beta 5-\mathrm{L}$ in rods of the $\mathrm{G} \beta 5^{-/-}$animals restored normal photoreceptor recovery but failed to rescue the OPL morphological defect as the number of OPL synaptic triads remains low in adult TG $\beta 5 \mathrm{~L}^{-/-}$animals (Fig. $3 F$ ).

\section{Discussion}

\section{G $\beta 5$ is essential for normal development of OPL synapses between photoreceptors and bipolar cells}

We found, unexpectedly, abnormalities in the OPL of the $\mathrm{G} \beta 5^{-1-}$ mice, with short bipolar cell dendrites and reduction in number of synaptic triads at photoreceptor terminals. It has been reported that the ON-bipolar cells project neuroepithelial processes into the outer nuclear layer (ONL) until P7, followed by retraction of these processes from P7 to P9 (Morgan et al., 2006). The synaptic connections between photoreceptors and bipolar cells take shape between P10 to P14, during which ERG a-wave gradually develops and b-wave becomes recordable at the end of this period (Takada et al., 2004). The presence of G $\beta 5$-S over this critical period and the failure of $\mathrm{G} \beta 5^{-1-}$ mice to increase the number of synaptic triads strongly suggest a role of G $\beta 5-S$ in normal OPL synaptic development. This conclusion is further supported by similar OPL morphological defects found in the adult TG $\beta 5 \mathrm{~L}^{-/-}$mice, in which recovery of rod phototransduction appears normal but the ERG b-wave is missing. Intriguingly, the reduction of synaptic triads is more severe at rod spherules than at cone pedicles. It remains to be determined whether all types of cone ON-bipolar cells or just a subset are affected. Systematic restoration of G $\beta 5-S$ in selective retinal layers or inducible expression at different developmental stages may thus provide valuable insight into the cellular origin of this OPL phenotype.

\section{A role of $\mathrm{G} \beta 5-\mathrm{S}$ and $\mathrm{R} 7 \mathrm{RGS}$ proteins in the mGluR6 pathway of the ON-bipolar cells?}

In the dark, glutamate released from photoreceptor terminals nearly saturates the mGluR6 metabotropic glutamate receptor located at the tips of the ON-bipolar cell dendrites (Sampath and Rieke, 2004). Activated mGluR6 couples to Go $\alpha$ (Nawy, 1999; Dhingra et al., 2000) and through an unknown mechanism closes cation channels resulting in membrane hyperpolarization. Upon illumination, the release of glutamate dwindles allowing ONbipolar cells to reopen the channels and depolarize their membranes. This depolarization appears as a light-induced positivegoing corneal potential in ERG and is referred to as the b-wave, which immediately follows the photoreceptor-driven negative potential (a-wave). All R7 RGS proteins, when complex with $\mathrm{G} \beta 5$-S, accelerate the hydrolysis of GTP by Go $\alpha$ in vitro (Hooks et al., 2003). Because G $\beta 5-S$, RGS11, and RGS7 are present at the OPL, where ERG b-wave originates, it is not unreasonable to speculate that G $\beta 5$-S/RGS7 and/or G $\beta 5$-S/RGS11 participates in the mGluR6 signaling pathway by acting as the GAP for Go $\alpha$. It is reported that failure to deactivate Go $\alpha$ abolishes the light responses of rod ON-bipolar cells (Sampath and Rieke, 2004). The absence of both scotopic (Fig. $1 A$ ) and photopic ERG b-waves in the $\mathrm{G} \beta 5^{-1-}$ mice, in which all R7 RGS proteins are downregulated (Chen et al., 2003), is consistent with the notion that sustained mGluR6 and Go $\alpha$ signaling abolishes light responses of ON-bipolar cells. The speculation that G $\beta 5$-S/RGS7 and/or G $\beta 5$ S/RGS11 regulates GTP hydrolysis of Go $\alpha$ is apparently at odds with the notion that Ret-RGS1 is the physiological GAP for Go $\alpha$ in the ON-bipolar cells (Dhingra et al., 2004).

Are the two phenotypes of the $\mathrm{G} \beta 5^{-1-}$ mice reported here related? Lack of ERG b-wave does not necessarily cause morphological defects, exemplified by the normal OPL appearance of the Go $\alpha^{-1-}$ (Dhingra et al., 2000), mGluR6 ${ }^{-1-}$ (Tagawa et al., 1999), and nob animals (Ball et al., 2003). On the other hand, the OPL abnormality may be responsible for the observed no-b-wave phenotype. Whether the lack of ERG b-wave in $\mathrm{G} \beta 5^{-/-}$mice reflects synaptic abnormality, sustained mGluR6/Go $\alpha$ signaling, or both remains to be determined. A detailed characterization of other R7 RGS knock-out or tissue-specific G $\beta 5$ knock-out animals will be informative. Furthermore, it is interesting to determine whether RGS7 and RGS11 coexist in the same cells. The two novel phenotypes reported here signify the importance of G $\beta 5-S$ and the R7 RGS proteins in the CNS and the usefulness of the $\mathrm{G} \beta 5^{-/-}$mice to help unveil their physiological functions.

\section{References}

Ball SL, Pardue MT, McCall MA, Gregg RG, Peachey NS (2003) Immunohistochemical analysis of the outer plexiform layer in the nob mouse shows no abnormalities. Vis Neurosci 20:267-272.

Chen CK, Burns ME, He W, Wensel TG, Baylor DA, Simon MI (2000) Slowed recovery of rod photoresponse in mice lacking the GTPase accelerating protein RGS9-1. Nature 403:557-560.

Chen CK, Eversole-Cire P, Zhang H, Mancino V, Chen YJ, He W, Wensel TG, Simon MI (2003) Instability of GGL domain-containing RGS proteins in mice lacking the G protein beta-subunit Gbeta5. Proc Natl Acad Sci USA 100:6604-6609.

Dhingra A, Lyubarsky A, Jiang M, Pugh Jr EN, Birnbaumer L, Sterling P, Vardi N (2000) The light response of ON bipolar neurons requires G[alpha]o. J Neurosci 20:9053-9058.

Dhingra A, Faurobert E, Dascal N, Sterling P, Vardi N (2004) A retinalspecific regulator of G-protein signaling interacts with Galpha(o) and accelerates an expressed metabotropic glutamate receptor 6 cascade. J Neurosci 24:5684-5693.

Fain GL, Quandt FN, Bastian BL, Gerschenfeld HM (1978) Contribution of a caesium-sensitive conductance increase to the rod photoresponse. $\mathrm{Na}$ ture 272:466-469.

Hooks SB, Waldo GL, Corbitt J, Bodor ET, Krumins AM, Harden TK (2003) RGS6, RGS7, RGS9, and RGS11 stimulate GTPase activity of Gi family G-proteins with differential selectivity and maximal activity. J Biol Chem 278:10087-10093. 
Keresztes G, Martemyanov KA, Krispel CM, Mutai H, Yoo PJ, Maison SF, Burns ME, Arshavsky VY, Heller S (2004) Absence of the RGS9.Gbeta5 GTPase-activating complex in photoreceptors of the R9AP knockout mouse. J Biol Chem 279:1581-1584.

Kolb H (1977) The organization of the outer plexiform layer in the retina of the cat: electron microscopic observations. J Neurocytol 6:131-153.

Krispel CM, Chen CK, Simon MI, Burns ME (2003) Prolonged photoresponses and defective adaptation in rods of Gbeta5-/- mice. J Neurosci 23:6965-6971.

Li S, Chen D, Sauve Y, McCandless J, Chen YJ, Chen CK (2005) RhodopsiniCre transgenic mouse line for Cre-mediated rod-specific gene targeting. Genesis 41:73-80.

Lyubarsky AL, Naarendorp F, Zhang X, Wensel T, Simon MI, Pugh Jr EN (2001) RGS9-1 is required for normal inactivation of mouse cone phototransduction. Mol Vis 7:71-78.

Mansergh F, Orton NC, Vessey JP, Lalonde MR, Stell WK, Tremblay F, Barnes S, Rancourt DE, Bech-Hansen NT (2005) Mutation of the calcium channel gene Cacnalf disrupts calcium signaling, synaptic transmission and cellular organization in mouse retina. Hum Mol Genet 14:3035-3046.

Martemyanov KA, Lishko PV, Calero N, Keresztes G, Sokolov M, Strissel KJ, Leskov IB, Hopp JA, Kolesnikov AV, Chen CK, Lem J, Heller S, Burns ME, Arshavsky VY (2003) The DEP domain determines subcellular targeting of the GTPase activating protein RGS9 in vivo. J Neurosci 23:10175-10181.

Masu M, Iwakabe H, Tagawa Y, Miyoshi T, Yamashita M, Fukuda Y, Sasaki H, Hiroi K, Nakamura Y, Shigemoto R, et al (1995) Specific deficit of the ON response in visual transmission by targeted disruption of the mGluR6 gene. Cell 80:757-765.

Morgan JL, Dhingra A, Vardi N, Wong RO (2006) Axons and dendrites originate from neuroepithelial-like processes of retinal bipolar cells. Nat Neurosci 9:85-92.

Nawy S (1999) The metabotropic receptor mGluR6 may signal through
G(o), but not phosphodiesterase, in retinal bipolar cells. J Neurosci 19:2938-2944.

Pittler SJ, Baehr W (1991) Identification of a nonsense mutation in the rod photoreceptor cGMP phosphodiesterase beta-subunit gene of the rd mouse. Proc Natl Acad Sci USA 88:8322-8326.

Sampath AP, Rieke F (2004) Selective transmission of single photon responses by saturation at the rod-to-rod bipolar synapse. Neuron 41:431-443.

Slaughter MM, Miller RF (1981) 2-amino-4-phosphonobutyric acid: a new pharmacological tool for retina research. Science 211:182-185.

Snow BE, Krumins AM, Brothers GM, Lee SF, Wall MA, Chung S, Mangion J, Arya S, Gilman AG, Siderovski DP (1998) A G protein gamma subunitlike domain shared between RGS11 and other RGS proteins specifies binding to Gbeta5 subunits. Proc Natl Acad Sci USA 95:13307-13312.

Stockton RA, Slaughter MM (1989) B-wave of the electroretinogram. A reflection of ON bipolar cell activity. J Gen Physiol 93:101-122.

Tagawa Y, Sawai H, Ueda Y, Tauchi M, Nakanishi S (1999) Immunohistological studies of metabotropic glutamate receptor subtype 6-deficient mice show no abnormality of retinal cell organization and ganglion cell maturation. J Neurosci 19:2568-2579.

Takada Y, Fariss RN, Tanikawa A, Zeng Y, Carper D, Bush R, Sieving PA (2004) A retinal neuronal developmental wave of retinoschisin expression begins in ganglion cells during layer formation. Invest Ophthalmol Vis Sci 45:3302-3312.

Watson AJ, Katz A, Simon MI (1994) A fifth member of the mammalian G-protein beta-subunit family. Expression in brain and activation of the beta 2 isotype of phospholipase C. J Biol Chem 269:22150-22156.

Watson AJ, Aragay AM, Slepak VZ, Simon MI (1996) A novel form of the G protein beta subunit Gbeta5 is specifically expressed in the vertebrate retina. J Biol Chem 271:28154-28160.

Witherow DS, Wang Q, Levay K, Cabrera JL, Chen J, Willars GB, Slepak VZ (2000) Complexes of the $G$ protein subunit gbeta 5 with the regulators of G protein signaling RGS7 and RGS9. Characterization in native tissues and in transfected cells. J Biol Chem 275:24872-24880. 